\title{
A new ascarid species in cynodont coprolite dated of 240 million years
}

\author{
PRISCILLA A. DA SILVA ${ }^{1}$, VICTOR H. BORBA ${ }^{1}$, JULIANA M.F. DUTRA ${ }^{1}$, DANIELA LELES ${ }^{3}$, \\ ATILA A.S. DA-ROSA ${ }^{2}$, LUIZ F. FERREIRA ${ }^{1}$ and ADAUTO ARAUJO ${ }^{1}$ \\ ${ }^{1}$ Laboratório de Paleoparasitologia, Escola Nacional de Saúde Pública Sérgio Arouca, Fundação Oswaldo Cruz, \\ Rua Leopoldo Bulhões, 1480, Manguinhos, 21041-210 Rio de Janeiro, RJ, Brasil \\ ${ }^{2}$ Laboratório de Estratigrafia e Paleobiologia, Departamento de Geociências, Universidade Federal de Santa Maria, \\ Avenida Roraima, 1000, Prédio 17 - Sala 1131B, 97105-900 Santa Maria, RS, Brasil \\ ${ }^{3}$ Departamento de Microbiologia e Parasitologia, Instituto Biomédico, Universidade Federal Fluminense, MIP-UFF, \\ Rua Professor Hernani Melo, 101, São Domingos, 24210-130 Niterói, RJ, Brasil
}

Manuscript received on January 30, 2013; accepted for publication on April 4, 2013

\begin{abstract}
Cynodonts represent the transition from reptiles to mammals. They are classified as synapsids, or tetrapod animals with mammalian characteristics. We present here the finding of helminth eggs in a coprolite identified as of cynodont origin dated of nearly 240 million years. Microscopy revealed the presence of very well preserved intestinal parasite eggs. Up to now we identified an ascarid egg by morphological characteristics. Based on a previous description of the new genus Ascarites Poinar Jr and Boucot 2006 in coprolites of iguanodons from Belgium, we propose a new species, Ascarites rufferi n.sp. in cynodonts, a host that inhabited the Southern Region of Brazil in the Triassic period.
\end{abstract}

Key words: Ascarids, coprolites, cynodont, evolution, paleoparasitology.

\section{INTRODUCTION}

The finding of coprolites - desiccated, fossilized or permineralized feces - associated with skeletons of extinct animals is not uncommon (Souto 2000, 2011). Besides the possible presence of parasites, important information such as dietary habits, paleoclimate and paleoecological adaptations can be evidenced (Wolff et al. 2009). The first study was conducted by Renault and Bertrand (1895), describing structures classified as bacteria on vertebrate coprolites dated from the Permian of France. However, studies of parasites in this kind of material only recently began to be developed.

Correspondence to: Adauto Araujo

E-mail: adauto@ensp.fiocruz.br
The study of coprolites from extinct animals has revealed new species and genus of parasites, demonstrating its potential. Parasite eggs and cysts have been found in different extinct animals, such as unidentified nematode eggs in a giant sloth (Ringuelet 1957); oocysts of two new species of Coccidia Archeococcidia antiques and Archeococcidea nothrotheriopsae in coprolite of a giant sloth (Schmidt et al. 1992); nematode larva in an extinct hyena species (Ferreira et al. 1993); Toxocara canis eggs in an extinct hyena species (Bouchet et al. 2003); Paleoleishmania proterus in blood from the digestive tract of a sandfly preserved in amber (Poinar Jr and Poinar 2004); three new genera of fungi from two categories, mycorrhizal and 
epiphyllous, in dinosaurian (Isisaurus) coprolites (Sharma et al. 2005); Plasmodium dominicana in digestive tract of a mosquito of the genus Culex (Poinar 2005); Ascaridae eggs and protozoa cysts in a dinosaur coprolite from the Cretaceous of Belgium, showing the antiquity of that host-parasite relationship (Poinar Jr and Boucot 2006); oocysts of Eimeria sp. in coprolite of palaeollama (Fugassa et al. 2008) and a probable infection by Trichomonas gallinae in tyrannosaurid (Wolff et al. 2009).

The finding of cynodont coprolites in a fossiliferous deposit is herein first reported. These animals are classified as tetrapods synapsids of the order Therapsida that includes mammaliamorph reptiles (Schultz and Langer 2007), which appeared at the end of Permian (Benton and Harper 2009). Belonging to a monophyletic clade that gave rise to mammals (Kardong 1995), the cynodonts can be divided into mammalian cynodonts, which are the mammals themselves, and non-mammalian cynodonts, including the group of mammaliaphorm reptiles (Schultz and Langer 2007). Regarding diet, the non-mammalian cynodonts are classified as either carnivores or herbivores; these last are called gonfodonts (Battail 1983, Benton 2005, Schultz and Langer 2007). They were almost vanished with the mass extinction of the Permo-Triassic, which extinguished $90 \%$ of animal species, but after that the cynodonts have diversified and dominated the Triassic period (Benton 2005).

The presence of tetrapod fossils is well documented in paleontological excavations in Southern Brazil (Holz et al. 2010). Coprolites were found associated with fossils of these animals (Schultz et al. 2000, Da-Rosa et al. 2004, 2005).

Schultz and Langer (2007) recognized five different species belonging to this cenozone: Massetognathus ochagaviae (Barberena 1981); Chiniquodon theotonicus (Huene 1938); Traversodonst ahleckeri (Huene 1938); Luangwa sudamericana (Abdala and Sá-Teixeira 2004); Protheriodone studianti (Bonaparte et al. 2006). More recently,
Reichel et al. (2009) described a new traversodontid herbivorous form, Protuberum cabralensis, characterized by rib tuberosities. Fossils from Massetognathus and Traversodon (cynodonts with special dentition for herbivorous habits) are in great number. Chiniquodon theotonicus is the only species that possessed specialized teeth for carnivorous diet (Reichel et al. 2009).

On this paper we describe a new species of ascarid found in a herbivorous cynodont coprolite from the Triassic of Southern Brazil.

\section{MATERIALS AND METHODS}

The coprolite was collected and identified by a multidisciplinary group of the Universidade Federal de Santa Maria (UFSM). The paleontological site is called Cortado site, located at Rio Grande do Sul state, Brazil, at coordinates S 2944'55'; W $53^{\circ} 00^{\prime} 06^{\prime \prime}$ (Da-Rosa et al. 2004). The coprolite was found on Santa Maria Sequence 1 in Therapsida Cenozone, or Dinodontosaurus Association Zone, as it is called nowadays, dated as Ladinian (Schultz and Langer 2007) of Triassic Period (241 to 237 M.y., according to the most recent chronostratigraphic ICS and GSA charts) (Cohen et al. 2012, Walker et al. 2012).

Coprolites were identified based on their shape, content and associated fauna. Archosaurs and procolophonoids were discarded as the coprolite producers, for being too big or small, respectively. Dicynodonts recorded at the outcrops ranging from juvenile to adult forms, thus from medium to big size. Cynodonts in the outcrop occur as both forms, herbivores and carnivores. Herbivorous cynodonts are medium-sized forms, while carnivorous cynodonts are medium- to small-sized forms.

The coprolite was examined under stereomicroscope at $75 \mathrm{x}$ to look for macroscopic food remains on its surface. Texture and morphology were also examined.

The surface was scraped, and material was also extracted from the interior of the coprolite by 
using a drill. Instruments were sterilized before using. The small fragments were transferred into a Petri dish to separate smaller fragments that were placed into microtubes. Subsequently, the small fragments were treated with $10 \%$ hydrochloric acid $(\mathrm{HCl})$ to dissociate minerals, washing immediately with distilled water to cease reaction.

Each $100 \mu 1$ of demineralized sediment was used to settle 20 microscope slides for bright field microscopy analysis at 100x and 400x final magnification. A total of 550 slides were examined under light microscopy (275 slides of the coprolite surface and 275 from inside).

\section{RESULTS}

The coprolite has a cylindrical shape and a rough surface, with one subdivision at the middle. Food remains were not identified in the surface.

Microscopically, two different kinds of helminth eggs were identified. First, an egg with a round mammilated eggshell, measuring $62.60 \mathrm{x}$ $60.17 \mu \mathrm{m}$ (Figure 1); the other kind of egg is ovalshaped, with a double thin eggshell, measuring $106.52 \times 53.26 \mu \mathrm{m}$. Both eggs were found in the material collected from the interior of the coprolite.

\section{DISCUSSION}

The round mammilated egg is characteristic of the order Ascaridida, and was identified as such due to their morphological similarity assigned to this family (Figure 1). Parasites of this family are found in many mammals today, including aquatic mammals. Poinar Jr and Boucot (2006) found different eggs of Ascaridae in dinosaurs, identified as iguanodons, semi-aquatic reptiles. The eggs were described as a new genus and species of parasites, Ascarites priscus; Ascarites gerus. Although morphological characteristics are comparable, the ascarid egg in cynodont coprolite differs in size.

Considering the rules for description of a new species, it would be impossible to fulfill all the

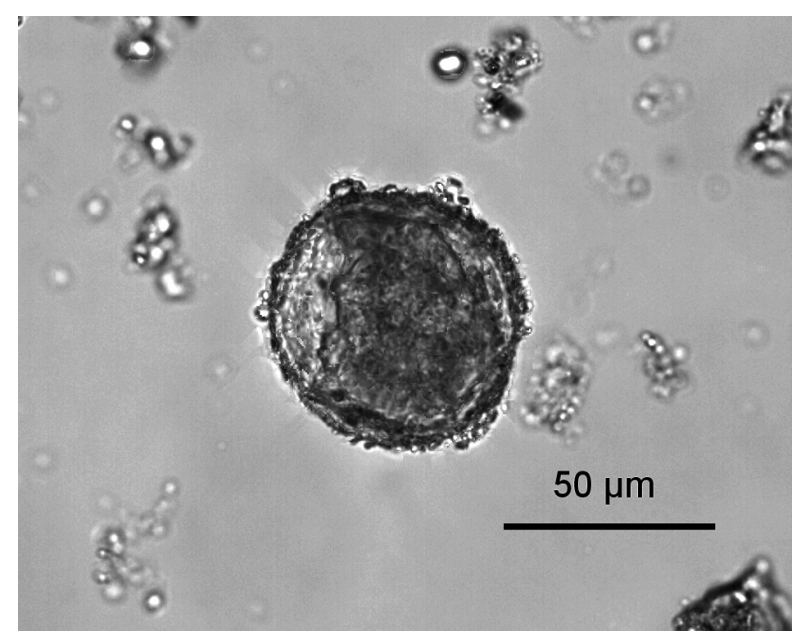

Figure 1 - Ascaridae egg found in cynodont coprolite dated 240 million years old.

steps required. In that case, there is a supposed host, a species of the cynodont group, and a parasite, a species of ascarid, of which the only trace found was an egg similar to current Ascaridae in their morphometry. Therefore, ascarid infection dated of 240 million years and apparently there was no distinct change in the eggs morphology of this group of parasite, enabling their identification. To follow the genus Ascarites proposed by Poinar Jr and Boucot (2006), we suggest the name of the species found in the cynodonts, Ascarites rufferi, in honor of Sir Marc Armand Ruffer, the first to register eggs of parasites in ancient material (Ruffer 1921).

A suggested classification is proposed below, following Poinar Jr and Boucot (2006):

Phylum: Nematoda (Rudolphi 1808)

Order: Ascaridida (Skrjabin and Shulz 1940)

Family: Ascarididae (Baird 1853)

Genus: Ascarites (Poinar and Boucot 2006)

Species: Ascarites rufferi n. sp.

Digital pictures of the egg are kept in the Data Bank of the Laboratory of Paleoparasitology, Fundação Oswaldo Cruz.

The cynodonts were both herbivores and carnivores, therefore, presence of ascarids is consistent with parasitism of this group in current species, 
but the parasitism by ascarids is also common in omnivores such as pigs and humans (Leles et al. 2012). The long persistence of parasitism and its breadth and diversity of hosts attests to the success of this group of nematodes.

Because these animals represent a group of transition from reptiles to mammals, as long as 240 million years, this finding shows how old the infection is, as well as the presence of this parasite in a host that would be the ancestor of mammals. The egg morphology was preserved for million of years, allowing it to be identified by the usual microscopic techniques.

As for the other kind of helminth egg found in the cynodont coprolite, studies are still in course.

The finding of these parasite eggs in Cynodontia shows the antiquity of parasitism at the reptile-mammal transition point, some 240 million years ago. This shows that, contrary to what was previously thought, there are fossil records of nematodes. Dorris et al. (1999) went as far as to state that the absence of fossils made it impossible to date the stages of evolution in nematodes. The present finding and other previous results (Dentzien-Dias et al. in press) show the ability of paleoparasitology to find evidence of parasitism in extinct animals, enhancing the potential of studies in fossils dating from millions of years. Lastly, this is an evidence of parasitism in a group of hosts that were ancestors of mammals, showing the scope for comparative studies, which for the moment are limited to morphology.

\section{ACKNOWLEDGMENTS}

This work was supported by the Brazilian agencies Conselho Nacional de Desenvolvimento Científico e Tecnológico (CNPq), Fundação Carlos Chagas Filho de Amparo à Pesquisa do Estado do Rio de Janeiro (FAPERJ), and Coordenação de Aperfeiçoamento de Pessoal de Nível Superior (CAPES)/CNPq (Ciência sem Fronteiras). We would like to thank the valuable suggestions of the two reviewers.

\section{RESUMO}

Cinodontes representam o passo de transição de répteis para mamíferos. São classificados como sinapsídeos, ou tetrápodes, animais com características de mamíferos. Apresentamos aqui o achado de ovos de helmintos em um coprólito identificado como originário de cinodontes, datado de cerca de 240 milhões de anos antes do presente. A microscopia revelou a presença de ovos de parasitos intestinais muito bem preservados. Até o momento, identificamos um ovo de ascarídio pelas características morfológicas. Baseados na descrição prévia do novo gênero Ascarites Poinar Jr e Boucot 2006 em coprólitos de iguanodontes na Bélgica, propomos uma nova espécie, Ascarites rufferi n.sp. em cinodontes, um hospedeiro que habitava a região sul do Brasil no período Triássico.

Palavras-chave: Ascarideos, coprólitos, cinodontes, evolução, paleoparasitologia.

\section{REFERENCES}

BATTAIL B. 1983. La phylogenie des cynodontes gonphodontes. Acta Palaeont. Polonica 28: 1-2, 19-30.

Benton M. 2005. Vertebrate Paleontology. $3^{\text {rd. }}$ ed., Bristol: Blackwell Publishing, $472 \mathrm{p}$.

BENTON M AND HARPER D. 2009. Introduction to paleobiology and the fossil record. $1^{\text {st }}$ ed., Oxford: Wiley-blackwell, $560 \mathrm{p}$.

Bouchet F, Guidon N, DitTMar K, Harter S, Ferreira LF, Chaves SM, Reinhard K and Araujo A. 2003. Parasite remains in archaeological sites. Mem Inst Oswaldo Cruz 98: 47-52.

COHEN KM, FInNEY S AND GIBBARD PL. 2012. International Chronostratigraphic Chart: International Commission on Stratigraphy. www.stratigraphy.org (last accessed May 2012).

DA-Rosa AAS, SchWANKe C, AURELIO PLP, PoITEVIN M AND Witeck Neto L. 2005. Sítio Linha Várzea - uma nova assembleia fossilífera do Triássico Médio do sul do Brasil. Geociências 24: 115-129.

DA-Rosa AAS, SchWANKe C, Cisneros JC, Witeck Neto L, AURELIo PLP AND PoITEVIN M. 2004. Sítio Cortado - Uma nova assembleia fossilífera para o Triássico Médio do sul do Brasil. Rev Bras Paleontol 7: 289-300.

DentZiEn-Dias PC, Poinar JR G, De Figueiredo AE, PaCheCo AC, HoRn BL AND SCHULTZ CL. IN PRESS. Tapeworm eggs in a 270 million-year-old shark coprolite. PLoS One 8(1): e55007. doi: 10.1371/journal.pone.0055007.

Dorris M, DE LEY P AND BLAXTER ML. 1999. Molecular analysis of nematode diversity and the evolution of parasitism. Parasitol Today 15: 188-193. 
Ferreira LF, Araujo A AND DUARTE AN. 1993. Nematode larvae in fossilized animal coprolites from lower and middle Pleistocene sites, central Italy. J Parasitol 79: 440-442.

Fugassa M, Sardella NH, Taglioretti V, Reinhard KJ AND ARAUJO A. 2008. Eimeriid oocysts from archaeological samples in Patagonia, Argentina. J Parasitol 94: 1418-1420.

Holz M, Bertoni-Machado C AND Simões MG. 2010. A estratigrafia de sequências e o registro fóssil. In: CARVALHO IS (Org), Paleontologia, Rio de Janeiro: Interciência, p. 111-138.

KARDONG K. 1995. Vertebrate: comparative anatomy, function, evolution. Dubuque: WCB Publishers, 777 p.

LELES D, GARDNER SL, REINHARD K, IÑIGUEZ A AND ARAUJO A. 2012. Are Ascaris lumbricoides and Ascaris suum a single species? Parasit Vectors 5: 42.

POINAR JR G 2005. Plasmodium dominicana n. sp. (Plasmodiidae: Haemospororida) from Tertiary Dominican amber. Syst Parasitol 61: 47-52.

PoINAR JR G AND Boucot AJ. 2006. Evidence of intestinal parasite of dinosaurs. Parasitology 133: 245-249.

POINAR JR G AND POINAR R. 2004. Paleoleishmania proterus n. gen., n. sp., (Trypanosomatidae: Kinetoplastida) from Cretaceous Burmese amber. Protist 155: 305-310.

Reichel M, Schultz CL And SoARes M. 2009. A new traversodontid cynodont (Therapsida, Eucynodontia) from the Middle Triassic Santa Maria Formation of Rio Grande do Sul, Brazil. Palaeontology 52: 229-250.

RenAult B AND BerTRAND CE. 1895. Premières observations sur des bactéries coprophiles de l' époque Permiènne. Sciences (CR, Caenoizoique 1) 894: 583-587.

RiNGUELET RA. 1957. Restos de probables huevos de nematodes en el estiércol del edentado extinguido Mylodon listai (Ameghino). Ameghiniana 1: 15-16.
RUFFER MA. 1921. Studies in paleopathology of Egypt. $1^{\text {st }}$ ed., Nova York: University of Chicago Press, 546 p.

SCHMIDT G, DUSZYNSKI D AND MARTIN P. 1992. Parasites of the extinct shasta ground sloth Nothrotheriops shastensis, in Rampart Cave, Arizona. J Parasitol 78: 811-816.

SCHUlTZ CL AND LANGER MC. 2007. Tetrápodes triássicos do Rio Grande do Sul, Brasil. In: CARVALHO IS (Org), Paleontologia: Cenários de Vida, Rio de Janeiro: Interciência, p. 269-282.

SCHUltz CL, Scherer CMS AND BARBERENA MC. 2000. Biostratigraphy of southern Brazilian middle-upper Triassic. Rev Bras Geoc 30: 491-494.

Sharma N, Kar RK, Agarwal A AND Kar R. 2005. Fungi in dinosaurian (Isisaurus) coprolites from the Lameta Formation (Maastrichtian) and its reflection on food habit and environment. Micropaleontology 51: 73-82.

SouTO PRF. 2000. Tetrapode coprolites from the middle Triassic of southern Brazil. Gaia, Geosci J 16: 51-57.

SoUTO PRF. 2011. Estudo de micro inclusões em coprólitos. In: Ferreira LF, Reinhard K and Araujo A (Orgs), Fundamentos da Paleoparasitologia, Ed Fiocruz, Rio de Janeiro, p. 153-159.

WALKER JD, GEISSMAN JW, BOWRING SA AND BABCOCK LE. 2012. Geologic Time Scale v. 4.0: Geological Society of America. http://www.geosociety.org/science/timescale/ timescl.pdf (last accessed May 2012).

WOLFF EDS, SLISBURY SW, HoRnER JR AND VARRICCHIO DJ. 2009. Common avian infection plagued the tyrant dinosaurs. PLoS ONE 4: e7288. 